\title{
Esterases from the Seeds of an Edible Legume, Phaseolus vulgaris L.; Variability and Stability during Germination
}

\author{
Syed Azmal Ali ${ }^{1}$, Grishma Bendre ${ }^{1}$, Shraddha Ojha ${ }^{1}$, V. Krishnamurthy ${ }^{1}$, N. Ramachandra Swamy ${ }^{2}$, \\ Kempohalli S. Chandrashekharaiah ${ }^{*}$ \\ ${ }^{1}$ Department of Biotechnology, PES Institute of Technology, Bangalore, India; ${ }^{2}$ Department of Biochemistry, Bangalore University, \\ Bangalore, India. \\ Email: "kschandraks@gmail.com
}

Received March 2nd, 2013 ; revised April 2nd, 2013 ; accepted April 10² 2013

Copyright (C) 2013 Syed Azmal Ali et al. This is an open access article distributed under the Creative Commons Attribution License, which permits unrestricted use, distribution, and reproduction in any medium, provided the original work is properly cited.

\begin{abstract}
The total protein and esterase were isolated from the seeds of Red Kidney beans (Phaseolus vulgaris). The crude protein content was observed as $15 \%$. The germination of seeds of red kidney bean has been carried out and change in the total protein content and esterase activity was monitored. The protein content was decreased from 15\% (24 hours) to 8\% (144 hours) during germination. The socked seeds and seedlings of all the days of germination exhibited esterase activity. Maximum ester hydrolyzing activity was observed on 6th day of germination whereas as lowest ester hydrolyzing activity was observed 2nd day germination. Native PAGE was carried out and esterase banding pattern for two different artificial substrates was studied. The esterase banding pattern in presence of 1-Napthyl acetate showed the presence of 4 esterolytic bands while 2 esterolytic bands were observed in presence of 2-Napthyl acetate.
\end{abstract}

Keywords: Esterase; Phaseolus vulgaris; Germination; Variability; Stability

\section{Introduction}

Esterases are hydrolytic enzymes predominantly present in all living organisms including micro-organisms, plants and animals. These enzymes catalyze the hydrolysis of various types of esters with broad substrate specificity. Esterases are widely distributed in nature and occur in multiple molecular forms. The biological functions of these enzymes are multifaceted. They are involved in fruit ripening, abscission, cell expansion, reproduction as well as hydrolysis of ester containing xenobiotic molecules [1].

Esterases are a family of metabolic enzymes that contains $\alpha / \beta$ hydrolase fold and only few of them have been studied in plants. The other functions of esterases include metabolism and subsequent detoxification of many agrochemicals and pharmaceuticals [2,3], metabolism of number of therapeutics [4] including the cholesterollowering drug, lovastatin [5], the anti-influenza drug, oseltamivir (Tamiflu) [6], the narcotic analgesic meperidine [7], cocaine and heroin [8]. The esterases are also extensively used in soft and pro drug design [9-11].

\footnotetext{
"Corresponding author.
}

The genus Phaseolus belongs to family leguminosae, subfamily Papilionoideae, and includes over 50 species [12]. Leguminous plants are rich in both micro and macro nutrients and are consumed by many people around the world as a source of protein, carbohydrate, fiber, vitamins and minerals. Phaseolus vulgaris is an edible legume containing protein concentration up to $17 \%-19 \%$ (dry weight). Intake of dry legumes can help controlling the lipid homeostasis and consequently reduce risk of CVD, Diabetes, Digestive tract disease, Overweight and Obesity [13]. Legumes also contain protease inhibitors, lectins and phytates as protective micro-constituents against cancer [14]. Phaseolus vulgaris is a common bean which is an important dietary vegetable and main protein source in diet of people of many countries [15]. The protein content of common bean varies from $15 \%$ $25 \%$ and carbohydrate content varies from $40 \%-60 \%$. The common bean is a good source of iron which is required for many proteins including hemoglobin, myoglobin, catalase and oxidoreductases. Since no work on esterases has been carried out and esterases might be involved in many functions, the present work is aimed to study the esterases from the seeds of Phaseolus vulgaris. 


\section{Materials and Methods}

\subsection{Materials}

\subsubsection{Plant Material}

Seeds of Phaseolus vulgaris were obtain from the local market of Bangalore, India.

\subsubsection{Chemicals}

Acrylamide, N, N, Methylene bisacrylamide, $\alpha$-Naphthyl acetate, $\beta$-Napthyl acetate, bovine serum albumin, Fast blue RR and Diazo Blue-B were obtained from Sigma Chemical Company USA. All other chemical were of analytical grade.

\subsection{Methods}

\subsubsection{Germination of Seeds}

The seeds of Phaseolus vulgaris were germinated up to 144 hours in sterile sand (acid washed) and seedlings were collected at 24 hours interval.

\subsubsection{Preparation of Acetone Powder}

Acetone powder was prepared for all seedlings by blending with chilled acetone (10\%), followed by filtration using suction pump. The cake obtained was dried at $37^{\circ} \mathrm{C}$ and powdered. It was stored at $0^{\circ} \mathrm{C}-4^{\circ} \mathrm{C}$ until further use.

\subsubsection{Preparation of Crude Protein Extract}

A 10\% crude protein extract of the acetone powder of all seedlings of Phaseolus vulgaris were extracted using sodium phosphate buffer $(0.1 \mathrm{M})$, $\mathrm{pH} 7$ by stirring over magnetic stirrer at $0^{\circ} \mathrm{C}-4^{\circ} \mathrm{C}$ for $2 \mathrm{hrs}$. The extract was then centrifuged at $10,000 \mathrm{rpm}$ for 15 mins at $4^{\circ} \mathrm{C}$, the supernatant obtained was collected.

\subsubsection{Ammonium Sulphate Fractionation}

The crude protein extracts from all the seedlings were subjected to ammonium sulphate fractionation. Solid ammonium sulphate was added slowly with constant stirring over magnetic stirrer at $4^{\circ} \mathrm{C}$ to obtain $0 \%-80 \%$ saturation. The solution was allowed to stand for $1 \mathrm{hr}$ at $0^{\circ} \mathrm{C}-4^{\circ} \mathrm{C}$, centrifuged at $10,000 \mathrm{rpm}$ for 30 minutes. The protein pellet obtained was dissolved in sodium phosphate buffer, $\mathrm{pH} 7$ and dialysed against the same buffer.

\subsubsection{Protein Assay}

The protein content from all the extracts were determined according to method of Lowry et al. (1951) using bovine serum albumin as standard.

\subsubsection{Esterase Assay}

Quantitatively esterase activity was determined using method of Gomori [16] as modified by Van Asperen [17].
A typical assay mixture consists of $5 \mathrm{ml}$ of $0.3 \mathrm{mM}$ substrate solution (a stock solution of $30 \mathrm{mM} \alpha$-naphthyl acetate was prepared in acetone and 100 fold dilution of working solution was obtained in sodium phosphate buffer $\mathrm{pH} 7.0(0.1 \mathrm{M})$. The reaction was allowed to stand at room temperature for 15 minutes and it was stopped by adding $1 \mathrm{ml}$ of DBLS reagent (5 parts of 5\% sodium lauryl sulphate and 2 parts of $1 \%$ diazo blue-B). The solution was then allowed to stand for 30 minutes and absorbance of colour developed was read at $600 \mathrm{~nm}$. A standard curve was prepared by using 1-naphthol.

Enzyme Unit: The esterase activity was expressed in terms of $\mu$ moles of product formed per minute at room temperature.

\subsubsection{Electrophoresis}

An anionic native PAGE was carried out according to the method of Ornstein [18] and Davis [19]. A discontinuous gel system containing $7.5 \%$ of separating gel and $5 \%$ stacking gel was used. The separating gel composition was $0.325 \mathrm{M}$ Tris-HCl buffer ( $\mathrm{pH}$ 8.8), four parts of acrylamide-bisacrylamide solution (30 g acrylamide + $0.8 \mathrm{~g}$ bisacrylamide in $100 \mathrm{ml}$ of distilled water). The stacking gel composition was $0.125 \mathrm{M}$ tris $\mathrm{HCl}$ buffer $\mathrm{pH}$ 6.8, one part of acrylamide-bisacrylamide solution (14.6 $\mathrm{g}$ acrylamide $+0.4 \mathrm{~g}$ bisacrylamide dissolved in $100 \mathrm{ml}$ of distilled water). The ammonium persulphate and TEMED were used as polymerizing agents. After the polymerization the gel was kept in electrophoresis chamber which is connected to electrode and filled with glycine buffer (14.2 g glysine $+3 \mathrm{~g}$ tris diluted to $600 \mathrm{ml}$ of water). Suitable dilution of sample protein $(100 \mu \mathrm{g})$ with $20 \%$ glycerol containing bromophenol blue, were loaded individually in each well and kept in incubation of $4^{\circ} \mathrm{C}$ and subjected to electrophoresis by giving current of 2 $\mathrm{mA} /$ well for 4.5 hours.

\subsubsection{Staining for Proteins}

Proteins were stained on poly acrylamide gel using $0.5 \%$ solution of coomassive brillant blue R-250 solution in $25 \%$ methanol with $7.5 \%$ acetic acid in water for 1 hour and distaining is carried out in 25\% methanol and $7.5 \%$ acetic acid in water for overnight.

\subsubsection{Staining for Esterase Activity}

Esterases activity was detected on polyacrylamide gel using the method of Hunter and Markert [20]. Fast blue RR was used for coupling 1 \& 2-Napthol which were released upon hydrolysis of 1 \& 2-Napthyl acetate. The gels were removed from plates and stained for esterases activity using $100 \mathrm{ml}$ of $0.1 \mathrm{M}$ phosphate buffer $\mathrm{pH} 7.0$ containing $40 \mathrm{mg}$ of fast-blue RR and $20 \mathrm{mg}$ of 1 \& 2Naphthyl acetate (dissolved in $2 \mathrm{ml}$ of acetone) for 20 
minutes at room temperature.

\section{Results and Discussion}

Seed germination is the early and the critical stage during the growth and development of the plants. During germination complex biochemical and physiological changes occurs which brings metabolically inactive embryonic cells into active stage. The storage protein is one among the three major food reserves in plant seeds which were synthesized during the process of maturation and stored in the storage organs of the plants such as seeds. These stored proteins degraded and provide energy and nitrogen required for germination and subsequent growth of seedlings.

During germination and plant growth metabolic changes occurred can be correlated with variation in the types and level of several hydrolytic enzymes and soluble proteins. The results obtained in the present study also showed variation in the ester hydrolyzing activity and total soluble proteins in the endosperm of the seeds of Phaseolus vulgaris during germination. The total protein content and total ester hydrolyzing activity during germination of Phaseolus vulgaris seeds is shown in Figure 1. It is observed that, there was a steep decrease in protein content from 1st day to 2nd day, gradual increase in 3rd day followed by gradual decrease thereafter (up to 6th day) during germination. These observed changes in the total protein content indicated their involvement in physiological activity during germination.

Analysis of ester hydrolyzing activity during germination of Phaseolus vulgaris seeds showed that activity was gradually increased throughout the germination and reached maximum on 6th day of germination. This increased ester hydrolyzing activity indicated their requirement during growth and development of the plants. Similar changes were observed in protein content, soluble protein and protein fractions in the geminated seedling of Barley and Dolichos lablab [21,22].

Electrolytic analysis of proteins reveals the presence of total 6 bands in the soaked seeds of Phaseolus vulgaris. All the protein bands and ester hydrolyzing bands were numbered from anodic end. Among six protein bands, band 1,3 , and 4 are major and remaining bands were minor. The intensity of the major band decreased throughout the germination. Similarly, the intensity of minor bands decreased up to the 4th day of germination and completely disappeared there onwards. The electrophoretic ester hydrolyzing activity and protein banding pattern during germination of Phaseolus vulgaris is shown in Figure 2.

A total of 4 ester hydrolyzing bands were present with 1-Napthyl acetate as a substrate and 2 ester hydrolyzing activity bands were observed with 2-Napthyl acetate in the endosperm of Phaseolus vulgaris seeds. Among the 4 esterolytic bands observed, intensity of all the 4 esterolytic bands decreased on the 2nd day of germination and intensity of esterolytic bands 3 and 4 almost remained same up to 4th day of germination and disappeared thereafter. The major esterolytic bands 1 and 2 were present throughout the germination. Similarly, this esterolytic activity was also observed in the presence of 2-Napthyl acetate indicating the requirement of esterolytic activity required during the growth and development of the plants. Similar results were obtained in case of germination of seeds of Mucuna purinens [1].

\section{Conclusion}

The protein profile of Phaseolus vulgaris indicated that the seeds are good sources of proteins for consumption as a food source. The protein profile during germination suggests that stored proteins are mobilized for the synthesis of energy and new proteins required for the growth

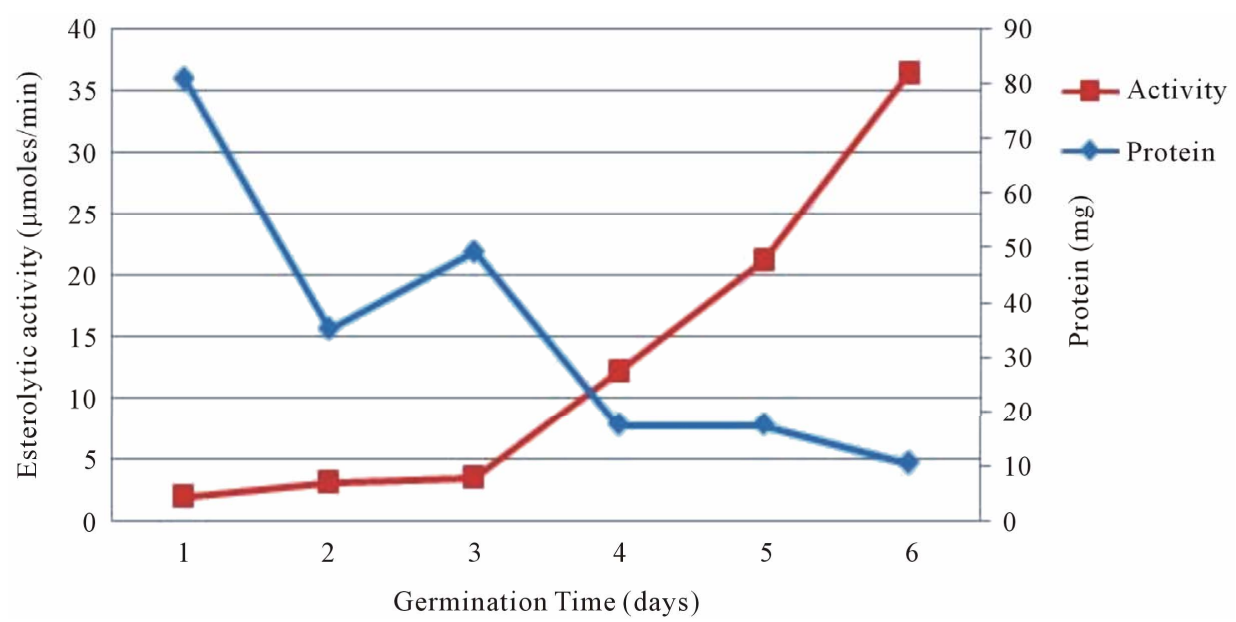

Figure 1. Esterolytic activity and protein profile of seeds of Phaseolus vulgaris during germination. 


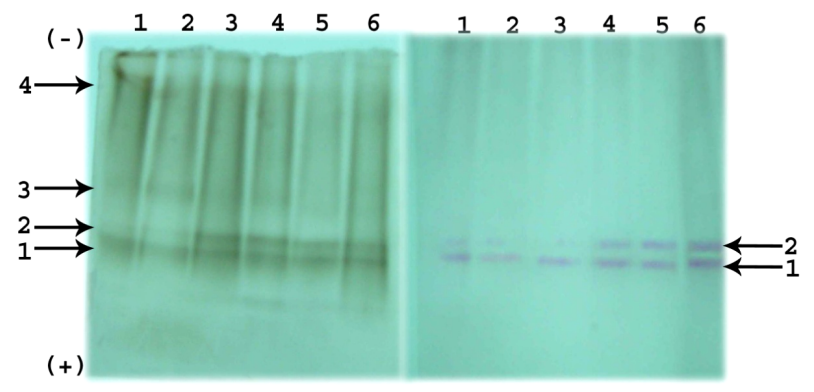

(a)

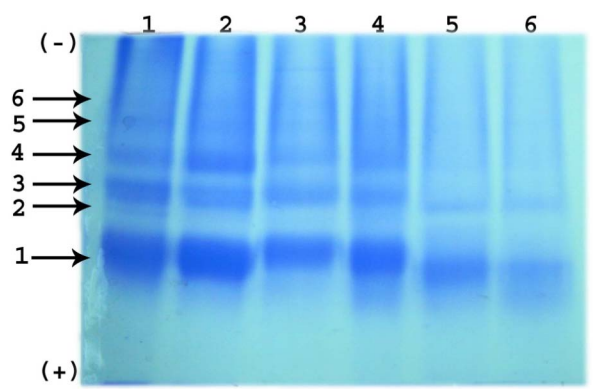

(b)

Figure 2. (a) Electrophoretic pattern of Esterases with 1Napthyl acetate and 2-Napthyl acetate; (b) Electrophoretic pattern of Protein during germination of Phaseolus vulgaris seeds.

and development of the plant. Similarly, the increase in the esterolytic activity suggest that these hydrolytic enzymes required for the complex metabolic activity occurs during growth and development of the plants. However, further studies are required for the characterization of esterolytic enzymes to explain the exact function in the plants.

\section{Acknowledgements}

The author wish to thank Dr. M. R. Doreswamy, Founder Chairman, PES group of institution Bangalore, Prof. D. Jawahar, CEO, PES group of institution Bangalore and Dr. K. N. B. Murthy, Principal, PES Institute of Technology, Bangalore for providing research facility to carryout present work.

\section{REFERENCES}

[1] K. S. Chandrashekharaiah, K. R. S. Murthy, N. R. Swamy, "Carboxylesterases (Purification and Characterization)," Verlag: LAP Lambert Academic Publishing GmbH and Co. KG, Saarbrücken, 2011, pp. 13-150.

[2] M. R. Redinbo and P. M. Potter, "Mammalian Carboxylesterases: From Drug Targets to Protein Therapeutics," Drug Discovery Today, Vol. 10, No. 5, 2005, pp. 313-325. doi:10.1016/S1359-6446(05)03383-0

[3] P. M. Potter and R. M. Wadkins, "Carboxylesterases: Detoxifying Enzymes and Targets for Drug Therapy,”
Current Medicinal Chemistry, Vol. 13, No. 9, 2006, pp. 1045-1054. doi:10.2174/092986706776360969

[4] F. M. Willams, "Clinical Significance of Esterases in Man," Clinical Pharmacokinetics, Vol. 10, No. 5, 1985, pp. 392-403. doi:10.2165/00003088-198510050-00002

[5] B. K. Tang and W. Kalow, "Variable Activation of Lovastatin by Hydrolytic Enzymes in Human Plasma and Liver," European Journal of Clinical Pharmacology, Vol. 47, No. 5, 1995, pp. 449-451. doi:10.1007/BF00196860

[6] D. Shi, J. Yang, D. Yang, L. Edward, L. Cluyse, C. Black, L. You, F. Akhlaghi and B. Yan, “Anti-Influenza Prodrug Oseltamivir Is Activated by Carboxylesterase Human Carboxylesterase 1, and the Activation Is Inhibited by Antiplatelet Agent Clopidogrel," The Journal of Pharmacology, Vol. 319, No. 3, 2006, pp. 1477-1484.

[7] J. Zhang, J. C. Burnell, N. Dumaual and W. F. Bosron, "Binding and Hydrolysis of Human Liver Carboxylesrerase hCE-1,” Journal of Pharmacology, Vol. 290, No. 1, 1999, pp. 314-318.

[8] E. V. Pindel, N. Y. Kedishvili, T. R. Abraham, M. R. Brzezinski, J. Zhang, R. A. Dean and W. F. Bosron, "Purification and Cloning of a Human Liver Carboxylesterase (hCE-2) That Catalyzes the Hydrolysis of Cocaine and Heroin,” Journal of Biological Chemistry, Vol. 272, 1997, pp. 14769-14775. doi:10.1074/jbc.272.23.14769

[9] N. Bodor and P. Buchwald, "Soft Drug Design: General Principle and Recent Applications,” Medicinal Research Reviews, Vol. 20, No. 1, 2000, pp. 58-101. doi:10.1002/(SICI)1098-1128(200001)20:1<58::AID-ME D3>3.0.CO;2-X

[10] N. Bodor and P. Buchwald, "Retrometabolism-Based Drug Design and Targeting,” In: D. J. Abraham, Ed., Drug Discovery and Drug Development Burger's Medicinal Chemistry and Drug Discovery, 6th Edition, John Wiley and Sons, New York, 2003, pp. 533-608.

[11] N. Bodor and P. Buchwald, "Designing Safer (Soft) Drugs by Avoiding the Formation of Toxic and Oxidative Metabolites,” Molecular Biotechnology, Vol. 26, No. 2, 2000, pp. 123-132. doi:10.1385/MB:26:2:123

[12] P. Gepts, “Phaseolus vulgaris (Beans),” 2001, pp. 1-2.

[13] M. Duranti, "Grain Legume Proteins and Nutraceutical Properties,” Fitoterapia, Vol. 77, No. 2, 2006, pp. 67-82. doi:10.1016/j.fitote.2005.11.008

[14] J. C. Mathers, "Nutrition Interacts with Genotype to Influence Health and Ageing," British Journal of Nutrition, Vol. 88, Suppl. 3, 2002, pp. 273-279. doi:10.1079/BJN2002717

[15] L. Da Silva Fialho, V. M. Guimarães, E. G. de Barros, M. A. Moreira, L. A. Dos Santos Dias, M. G. de Almeida Oliveira, I. C. José and S. T. de Rezende, "Biochemical Composition and Indigestible Oligosaccharides in Phaseolus vulgaris L. Seeds,” Plant Foods for Human Nutrition, Vol. 61, No. 2, 2006, pp. 87-89.

[16] O. H. Lowry, N. J. Rosebrough, A. L. Farr and R. J. Randall, "Protein Measurement with the Folin Phenol Reagent,” Journal of Biological Chemistry, Vol. 193, No. 1, 1951, pp. 265-275. 
[17] G. Gomori, “Human Esterases,” Journal of Laboratory and Clinical Medicine, Vol. 42, No. 3, 1953, pp. 445-453.

[18] K. Van Asperen, "A Study of Housefly Esterases by Means of a Sensitive Colorimetric Method," Journal of Insect Physiology, Vol. 8, No. 4, 1962, pp. 401-416. doi:10.1016/0022-1910(62)90074-4

[19] L. Ornstein, "Disc Electrophoresis I. Background and Theory," Annals of the New York Academy of Sciences, Vol. 121, 1964, pp. 321-349. doi:10.1111/j.1749-6632.1964.tb14207.x

[20] R. L. Hunter and C. L. Markert, "Histochemical Demonstration of Enzymes Separated by Zone Electrophoresis in
Starch Gels,” Science, Vol. 125, No. 3261, 1975, pp. 1294-1295. doi:10.1126/science.125.3261.1294-a

[21] M. Shastry and E. John, "Biochemical Changes and in Vitro Protein Digestibility of the Endosperm of Germinating Dolichos lablab," Journal of the Science of Food and Agriculture, Vol. 55, No. 4, 1991, pp. 529-538. doi:10.1002/jsfa.2740550405

[22] H. G. Sung, H. T. Shin, J. K. Ha, H. L. Lai, K. J. Cheng and J. H. Lee, "Effect of Germination Temperature on Characteristics of Phytase Production from Barley," Bioresource Technology, Vol. 96, No. 11, 2005, pp. 12971303. doi:10.1016/j.biortech.2004.10.010 